\title{
Reasons: A digital argument mapping library for modern browsers
}

\author{
Dave Kinkead ${ }^{1}$, Deborah Brown ${ }^{1}$, Peter Ellerton ${ }^{1}$, and Claudio \\ Mazzola $^{1}$
}

1 University of Queensland Critical Thinking Project

DOI: $10.21105 /$ joss.01044

\section{Software}

- Review ca

- Repository ${ }^{\top}$

- Archive ct

Submitted: 24 September 2018 Published: 12 May 2019

\section{License}

Authors of papers retain copyright and release the work under a Creative Commons Attribution 4.0 International License (CC-BY).

\section{Summary}

There is growing recognition globally of the need to teach Critical Thinking as part of formal schooling and of its importance to the "knowledge economies" of the future. Yet international research demonstrates that without explicit instruction in critical thinking, undergraduate education often results in little to no gains in critical thinking, analytic reasoning, and other "higher level" skills (Harrell, 2004, Arum \& Roksa (2011)).

One very effective way to improving critical thinking is through argument mapping — the visual representation of an argument's logical structure. Argument mapping in paper form is common in philosophy courses and has a pedagogical pedigree that can be traced back to Wigmore (1913), Toulmin (1958), and Govier (1992). Argument mapping can improve critical thinking skills by offering students an opportunity to engage in metacogntive evaluation - evaluating the quality of their own, and others', reasoning.

Digital argument mapping as an educational tool has been validated by van Gelder (2002), Butchart et al (2009), and Mulnix (2012). Dwyer, Hogan, \& Stewart (2012) demonstrated that argument mapping improves concept recall compared with textual analysis; Twardy (2004 p2) that it produces cognitive gains three times that of other methods; and van Gelder (2005 p45) that the cognitive gains from one semester of explicit argument mapping are equivalent to that of an entire undergraduate degree.

Unfortunately, argument mapping is rarely used outside of philosophy classes owing either to a lack of instructor expertise or availability of tools appropriate to non-philosophical pedagogies. Current digital argument mapping tools are either desktop software, limiting their ability to be integrated into online courseware, or propriety and tighly coupled, limiting their access and extensibility.

Reasons seeks to bridge this gap by offering an open-source, loosely-coupled, web-based argument mapping library that can be integrated into a range of online coursewares and websites. The javascript library can be embedded into any HTML page and allows users to create, edit, share, and export argument maps (see https://reasons.io for an example). The API is designed to permit the integration of the three stages of informal logical analysis - identification of truth claims within arguments, the analysis of logical structure, and synthesis of logcial structure into writen form.

Development has been funded by a University of Queensland Teaching Innovation Grant and the software forms a key component of the UQ Critical Thinking Project's research program into digital and critical thinking pedagogies. The intended audience for this software includes education researchers and practitions in secondary and higher education. 


\section{References}

Arum, R., \& Roksa, J. (2011). Academically adrift: Limited learning on college campuses. University of Chicago Press. doi:10.7208/chicago/9780226028576.001.0001

Butchart, S., Forster, D., Gold, I., Bigelow, J., Korb, K., Oppy, G., \& Serrenti, A. (2009). Improving critical thinking using web based argument mapping exercises with automated feedback. Australasian Journal of Educational Technology, 25(2). doi:10.14742/ajet.1154

Dwyer, C. P., Hogan, M. J., \& Stewart, I. (2012). An evaluation of argument mapping as a method of enhancing critical thinking performance in e-learning environments. Metacognition and Learning, 7(3), 219-244. doi:10.1007/s11409-012-9092-1

Govier, T. (1992). What is a good argument? Metaphilosophy, 23(4), 393-409. doi:10. 1111/j.1467-9973.1992.tb00551.x

Harrell, M. (2004). The improvement of critical thinking skills in what philosophy is. Carnegie Mellon University. Retrieved May, 9, 2007. Retrieved from https://www.cmu. edu/dietrich/philosophy/docs/harrell/Improving_Critical_Thinking_Skills.pdf

Mulnix, J. W. (2012). Thinking critically about critical thinking. Educational Philosophy and Theory, 44(5), 464-479. doi:10.1111/j.1469-5812.2010.00673.x

Toulmin, S. E. (1958). Fields of argument and modals. In The uses of argument (pp. 11-40). Cambridge University Press. doi:10.1017/cbo9780511840005.005

Twardy, C. (2004). Argument maps improve critical thinking. Teaching Philosophy, 27(2), 95-116. doi:10.5840/teachphil200427213

Van Gelder, T. (2002). Argument mapping with reason! Able. The American Philosophical Association Newsletter on Philosophy and Computers, 2(1), 85-90. Retrieved from https://sites.google.com/site/timvangelder/publications-1/ argument-mapping-with-reason-able/ArgumentMappingwithReasonAble-APANewsletter. pdf

Van Gelder, T. (2005). Teaching critical thinking: Some lessons from cognitive science. College Teaching, 53(1), 41-48. doi:10.3200/ctch.53.1.41-48

Wigmore, J. H. (1913). The principles of judicial proof: As given by logic, psychology, and general experience, and illustrated in judicial trials (Vol. 1). Little, Brown, Retrieved from https://archive.org/details/principlesofjudi00wigm/ 